\title{
ENTREPRENEURIAL BUREAUCRACY: SEBUAH TUNTUTAN MUTLAK UNTUK MENUTUPCAPACITY GAP APARATUR BIROKRASI DALAM ERA OTONOMI DAERAH
}

\author{
Rahoyo, S.E., M.Si \\ Asih Niati, S.E., M.M. \\ Fakultas Ekonomi Universitas Semarang
}

Diterima: November 2018. Disetujui: Desember 2018. Dipublikasikan: Januari 2019

\begin{abstract}
The estuary of the overall policy of regional autonomy must be to improve the welfare of local and regional communities in general in all dimensions. For bureaucratic apparatus, on the one hand, it means that the level of community satisfaction with the various services provided by the bureaucracy as an extension of the government (read: state / state) that is responsible for managing the welfare of its citizens is a major measurement of the whole system bureaucracy has indeed carried out its functions and roles properly or not. In other words, the more local and regional communities are served more satisfactorily, the core spirit of regional autonomy is increasingly achieved. Conversely, the more people feel disappointed with the overall performance of bureaucratic services, the spirit of regional autonomy is in fact being ignored in fact. In that context, especially coupled with the fact that the demands of the community are increasingly fierce, their awareness of their political, economic and social rights has developed so far compared to a decade ago that the bureaucracy is required to be able to self-transform to become more productive, professional, efficient, effective, has a vision that is far ahead, and that is not less important is community-oriented (customers-oriented). In short, facing the challenges of an increasingly complex and advanced society life as it is today, also precisely in order to achieve the core spirit of regional autonomy, entrepreneurial bureaucracy becomes imperative.

Keywords: Entrepreneurial Bureaucracy, Apparatus, Regional Autonomy
\end{abstract}

\begin{abstract}
Abstrak
Muara dari keseluruhan kebijakan otonomi daerah (the overall policies of regional autonomy) haruslah pada peningkatan kesejahteraan masyarakat lokal dan regional secara umum dalam keseluruhan dimensinya. Bagi aparatur birokrasi, pada satu sisi, itu berarti bahwa tingkat kepuasan masyarakat terhadap berbagai layanan yang disediakan birokrasi sebagai kepanjangan tangan pemerintah (baca: negara/state) yang memang bertanggung jawab untuk mengurus kesejahteraan warganya menjadi tolok ukur utama (major measurement) apakah keseluruhan sistem birokrasi memang telah menjalankan fungsi dan perannya dengan semestinya atau belum. Dengan kata lain, semakin masyarakat lokal dan regional terlayani dengan lebih memuaskan, semangat inti (core spirit) otonomi daerah semakin tercapai. Sebaliknya, semakin masyarakat merasa kecewa dengan keseluruhan kinerja pelayanan birokrasi, roh dari otonomi daerah tersebut secara faktual sebenarnya sedang terabaikan. Dalam konteks itulah apalagi ditambah dengan kenyataan bahwa tuntutan-tuntutan masyarakat kini semakin beragaram, kesadaran akan hak politik, ekonomi dan sosial mereka pun telah berkembang begitu jauh dibanding satu dekade lalu birokrasi dituntut mampu melakukan transformasi diri (self transformation) untuk menjadi semakin poduktif, profesional, efisien, efektif, memiliki visi yang jauh ke depan, dan yang tak kalah penting adalah berorientasi pada masyarakat (customers-oriented). Singkat kata, menghadapi tantangan kehidupan masyarakat yang semakin kompleks dan maju seperti sekarang ini, juga justru demi tercapainya semangat inti otonomi daerah,, birokrasi yang berjiwa wirausaha (entrepreneurial bureaucracy) menjadi sesuatu yang imperatif.
\end{abstract}

Kata kunci: Birokrasi Entrepreneurial, Aparatur, Otonomi Daerah 


\section{Pendahuluan}

Apabila terdapat persoalan yang paling banyak dibicarakan khalayak terkait pengelolaan administrai publik di era otonomi daerah ini, persoalan itu adalah menyangkut tata-kelola pemerintahan yang baik (good governance). Hal ini bisa dipahami mengingat berhasil-tidaknya pembangunan yang dilakukan oleh negara, salah satunya, sangat ditentukan oleh kapasitas sumber daya manusia dan kapasitas kelembagaan pemerintah (Moeljarto Tjokrowinoto, 2002).

Secara formal, pemerintah Indonesia selama masa Orde Baru sebenarnya telah beberapa kali melakukan improvement di bidang ini. Medelina K. Hendytio mencatat, selama masa Orde Baru berkuasa, telah tiga kali dilakukan reformasi untuk menanggapi tuntutan tersebut. Reformasi pertama dilakukan pada masa dekade pertama Orde Baru memegang tampuk pimpinan pemerintahan. Tujuan reformasi birokrasi ketika itu adalah agar birokrasi menjadi semakin efisien dan efektif sehingga dapat mendukung stabibilas nasional. Reformasi kedua dilakukan pada awal 1980-an dalam bentuk privatisasi, deregulasi dan debirokratisasi. Reformasi kala itu lebih ditujukan untuk memotong segala bentuk praktik penyebab ekonomi biaya tinggi (high cost economy) seperti uang pelicin, korupsi dan prosedur yang berbelit-belit. Konteks situasi, terutama ekonomi, yang melatarbelakangi perlunya melakukan reformasi kedua tersebut adalah bahwa ketika itu negara sedang giat-giatnya melakukan perubahan strategi dari aktivitas industrialisasi substitusi impor menjadi industrialisasi dengan orientasi ekspor. Birokrasi dituntut untuk bisa mendukung kebijakan pemerintah di atas. Dan, ekonomi biaya tinggi yang ketika itu banyak disorot para pengamat, jelas merupakan salah satu penghambat kegiatan ekspor karena dengan ekonomi biaya tinggi tersebut produk-produk industri dalam negeri menjadi tidak kompetitif di pasar luar negeri. Sedangkan reformasi ketiga dilakukan awal tahun 1990-an di mana pemerintah pusat bertekad menciptakan pemerintahan (baca: birokrasi) yang bersih dan berwibawa. Agenda dan penerapan pengawasaan melekat (waskat) yang amat populer pada dekade itu merupakan salah satu aplikasi riil dari reformasi ketiga di atas.

Faktanya, setelah selama satu generasi coba diperbaiki guna memenuhi kualifikasi birokrasi yang kapabel, akuntabel dan responsif serta adaptif terhadap segala tuntutan kemajuan dan perkembangan kehidupan masyarakat, aparatur birokrasi kita ternyata 
tetap saja belum menunjukkan kemajuan yang berarti. Faisal Tamin, mantan Menteri Pendayagunaan Aparatur Negara pada masa Pemerintahan Megawati Soekarnoputri, mengungkapkan bahwa $60 \%$ dari seluruh pegawai negeri sipil di Indonesia tidak produktif dan tidak profesional. Laporan Bank Dunia 2003 menyebutkan, hampir separuh dari seluruh pejabat di Indonesia menerima pungli. Angka kemiskinan di Indonesia tahun 2007 juga masih bertengger pada kisaran 17\% lebih. Sementara, laporan Indonesian Corruption Watch (ICW) mengemukakan bahwa sepanjang Januari sampai dengan Desember 2004 ditemukan 239 kasus korupsi di berbagai daerah dengan berbagai aktor dan modus operandinya. Yang paling paradoksal adalah lahirnya peraturan-peraturan daerah (Perda) yang justru tidak pro-perekonomian pascapemberlakuan otonomi daerah. Mantan Ketua Kadin (Menteri Koordinator Kesejahteraan Rakyat Pemerintahan SBY-JK), Aburizal Bakri, mengemukakan, terdapat 1006 Perda yang memberatkan dunia usaha. Di satu sisi kemiskinan masih menjadi momok menakutkan, tetapi di sisi lain, pemerintah daerah (aparatur birokrasi) ber-euphoria-berpesta menikmati kebebasan politik dengan semena-mena melahirkan produk-produk hukum tanpa mempertimbangkan efek ekonomisnya bagi masyarakat. Di satu sisi, masalah kemandirian finansial merupakan salah satu problem utama yang dihadapi pemerintah daerah pada era otonomi daerah ini, tetapi di sisi lain, terutama para elit pemerintahannya, alih-alih berusaha menarik investasi agar kehidupan perekonomian daerah bisa berkembang dan pendapatan asli daerah (PAD) meningkat, mereka justru menutup dan menghambat perkembangan dunia usaha dengan melahirkan perda-perda di atas.

Fakta-fakta di atas menjadi bukti tak terbantahkan bahwa mental pegawai yang sekaligus feodalistis secara ironis masih mendominasi sikap dan perilaku mereka dalam sebuah praktik kehidupan negara bangsa (nation-state) yang sudah jauh berkembang. Semua itu jelas kontraproduktif terhadap semangat otonomi daerah. Padahal, idealnya, para aparatur birokrasi tersebut haruslah adaptif, responsif bahkan bila perlu proaktif menanggapi tantangan pesatnya perkembangan kehidupan politik, ekonomi dan sosial masyarakat yang dilayaninya. Di sinilah letak persoalannya: untuk bisa adaptif, responsif dan bahkan harus proaktif terhadap kemajuan dan perkembangan kehidupan masyarakat sebagai konsumennya, para aparatur birokrat tersebut haruslah memiliki jiwa wirausaha 
(entrepreneurial bureaucracy). Kenyataannya, mental itu masih jauh dari para aparatur birokrasi kita.

Makalah ini akan berusaha menyoroti pentingnya entrepreneurial bureaucracy (birokrasi yang berjiwa wirausaha) dalam era otonomi daerah. Pada bagian awal, makalah ini akan menunjukkan adanya capacity gap yang ada pada birokrasi kita. Selanjutnya, makalah ini akan berusaha menguraikan bahwa dalam batas-batas tertentu negara dan atau pemerintahan (baca: organisasi formal birokrasi) tak ubahnya sebuah perusahaan. Dengan demikian, prinsip-prinsip tata kelola perusahaan yang baik (good corporate governance) demi efektivitas, efisiensi, dan produktivitas sebuah perusahaan pun pasti bisa diterapkan untuk mencapai efektivitas, efisiensi dan produktivitas birokrasi. Pada bagian inilah, penulis akan berusaha menguraikan beberapa karakteristik jiwa wirausaha (entrepreneur spirit) dan secara khusus karakteristik birokrasi yang berjiwa wirausaha (entrepreneur bureaucracy). Di akhir makalah, penulis mencoba menghadirkan beberapa tantangan yang sangat potensil dihadapi dalam usaha mewujudkan entrepreneur bureaucracy di atas.

\section{Capacity Gap}

Isu desentralisasi pada dasarnya merupakan fenomena global sebagai tuntutan masyarakat yang merasakan bahwa pemerintahan yang besar dan perencanaan sentral tidak mampu memberikan hasil-hasil pembangunan yang diharapkan.

In the 1960s and 1970s, the international community had been a strong supporter of big government and central planning. When that did not bring the desired developmental outcomes, ... (I)n the 1990s, territorial decentralisation was promoted as the authentic path to development.

Apa yang dikemukakan oleh Mark Turner dan Owen Podger di atas merupakan salah satu faktor eksternal selain demokratisasi, ekonomi pasar, maraknya isu civil society di seluruh belahan dunia, dsb yang memicu kebijakan desentralisasi pemerintahan di Indonesia menuju otonomi daerah yang sebenarnya (authentically regional autonomy). Dari dalam negeri sendiri (faktor internal), perubahan konfigurasi politik pascatumbangnya pemerintahan Orde Baru, ketidakpuasan daerah atas kebijakan-kebijakan yang diambil pemerintah pusat selama ini, yang berbuntut pada isu 
separatisme dan balkanisasi, juga telah mendorong dikeluarkannya UU No 22/1999 yang kemudian direvisi menjadi UU No 32/2004 tentang Pemerintahan Daerah. Apalagi, secara geografis, Indonesia yang terdiri dari 13.677 pulau, terbentang hampir mencapai 5.000 kilometer dari timur ke barat dan 1.770 kilometer dari utara ke timur dan dengan penduduk lebih dari 200 juta jiwa, memang tidak mungkin diurus dengan sistem pemerintahan terpusat (sentralistik).

Melalui otonomi daerah yang otentik, diasumsikan akan terjadi efisiensi pemerintahan, pemerataan pembangunan yang lebih fair dan berkeadilan serta memperhatikan lokalitas, persaingan yang sehat antardaerah regional, dan yang paling utama mendekatkan pemerintahan kepada rakyat. Muara semua itu adalah semakin terjaminnya hak-hak politik, ekonomi, dan sosial masyarakat, munculnya partisipasi aktif masyarakat sebagai warga negara dalam perencanaan dan pelaksanaan pembangunan, dan pada akhirnya terciptanya suatu kondisi masyrakat yang lebih sejahtera.

Secara yuridis-formal, otonomi daerah memang telah mendapatkan pijakannya dengan lahirnya UU No 22/1999 (pascarevisi menjadi UU No 32/2004) dan dengan segala dinamikanya. Demikianpun, landasan yuridis formal itu baru memenuhi syarat perlu (required conditions) dan belum memenuhi syarat cukup (sufficient conditions) bagi tercapainya semangat awal (initial spirit) desentralisasi dan otonomi daerah. Para pengamat pada umumnya sepakat bahwa sufficient conditions tersebut terpenuhi ketika tercipta tatakelola pemerintahan yang baik (good governance). Tatakelola pemerintahan yang baik selalu menyangkut 3 institusi yang tidak terpisahkan, yakni state (negara), private sector (sektor swasta), dan society (masyarakat). Yang pantas dicatat, dari ketiga institusi tersebut, institusi negaralah yang paling memegang peranan penting untuk terwujudnya good governance yang mencakup partisipasi, penegakan hukum, transparansi, sikap tanggap (responsiveness), orientasi pada konsensus, kesetaraan, efektivitas dan efisiensi, akuntabilitas, serta visi strategis.

Dalam soal terakhir inilah telah terjadi jurang pemisah kapasitas (capacity gap) antara tuntutan masyarakat sebagai konsekuensi logis dari dinamika kehidupan politik, ekonomi dan sosialnya yang begitu cepat yang menghendaki dimilikinya kemampuan-kemampuan ideal oleh para kaum birokrat dengan kemampuan riil yang 
dimiliki para aparatur pemerintahan tersebut sebagai penyelenggara negara yang harus melayani kepentingan umum (as public servants).

Kondisi seperti itu pantas ditengarai sebagai akibat begitu lamanya birokrasi terkungkung dalam sebuah sistem politik yang sentralistis selama Orde Baru bercokol dalam pemerintahan sepanjang lebih dari 30 tahun. Stabilitas politik yang ketika itu dijadikan sebagai conditio sine qua non berjalannya program-program pembangunan yang telah dirancang pemerintah pusat, berimplikasi pula pada sistem hierarikis-komando dalam jajaran birokrasi. Justru karena itu, loyalitas (kepada atasan) kemudian menjadi kapasitas utama dan bahkan satu-satunya yang harus dimiliki para aparatur negara (birokrasi). Sejalan dengan itu, kinerja (performance) birokrasi diukur secara mekanis semata-mata bisa atau tidak melakukan perintah atasan tanpa diberi keleluasaan untuk mengembangkan kapasitas kreativitasnya guna menangkap dan mengartikulasikan serta memenuhi tuntutan-tuntutan riil masyarakat. Sejalan dengan itu, para birokrat pun lantas menjadi elemen negara yang elitis, arogan, feodal, dan bermental tuan-puan. Karenanya juga tak mengherankan bila kinerja para birokrat hingga saat ini terasa sangat tidak memuaskan seperti ditulis H. Didik Widitrismiharto berikut ini:

“... (B)irokrasi pemerintah dalam menjalankan fungsi pelayanan publik selalu berbelit-belit, kaku, arogan, lamban dan malas ... sering melakukan penyimpangan, pemborosan dan syarat KKN ... tidak efisien, tidak efektif dan tidak profesional”

\section{Entrepreneurial Bureaucracy}

Dalam batas-batas tertentu, lembaga formal birokrasi (dengan organisasi, personalia, mekanisme, prosedur dan tata aturan, dan sarana dan prasarananya) tak ada bedanya dengan lembaga bisnis. Kalaupun pada akhirnya memang ada perbedaan fundamental antara lembaga formal birokrasi dengan lembaga bisnis, hal itu adalah sifatnya. Lembaga bisnis bersifat profit (profit oriented) sedangkan lembaga formal birokrasi jelas merupakan lembaga nonprofit. Tetapi, prinsip-prinsip dasar pengelolaan kedua lembaga tersebut pada dasarnya tidak jauh berbeda.

Bila dalam manajemen lembaga profit yang sehat dikenal adanya perencanaan, pengorganisasian, pelaksanaan dan pengendalian yang harus dilakukan secara konsisten dan terukur (measurable), dalam birokrasi pun (seharusnya) ada. Bila dalam lembaga 
bisnis dikenal prinsip-prinsip efektivitas, efisiensi, produktivitas dan berorientasi pada pelanggan (customer-oriented), birokrasi pun seharusnya juga demikian. Dan, untuk mencapai semua itu, lembaga bisnis kini tidak cukup hanya menuntut sense of belonging dari para karyawannya, tetapi telah melompat jauh menjadi tuntutan adanya sense of entrepreneurship. Logikanya sangat sederhana: sebagus apa pun visi, misi, target, tujuan, struktur, prosedur dan aturan telah disusun, tanpa didukung personalia yang kompeten (memiliki sense of entrepreneurship) semua itu tinggal cita-cita ideal di atas kertas tetapi tidak pernah menjadi realitas.

Karenanya, dalam kehidupan ekonomi, politik, dan sosial masyarakat yang telah mengalami dinamika yang demikian jauh saat ini, syarat entrepreneurial para aparatur birokrasi pun menjadi tuntutan imperatif. Ini berarti pertama-tama harus terjadi transformasi dan pergeseran mental (mentally transformed-shifted bureaucracy) dari seorang pegawai menjadi seseorang yang berjiwa wirausaha. Menurut Peggy A. Lambing dan Charles R. Kuehl dalam bukunya Entrepreneurship sebagaimana dikutip oleh Ir. Hendro, MM, secara umum seorang wirausahawan memiliki empat unsur pokok yaitu kemampuan (hubungannya dengan IQ dan skill), keberanian (hubungannya dengan emotional quotient dan mental), keteguhan hati (hubungannya dengan motivasi diri), dan kreativitas. Selanjutnya Hendro merinci, kemampuan di situ menunjuk pada kemampuan dalam membaca peluang, berinovasi, mengelola dan memasarkan (bukan sekadar menjual!). Keberanian secara spesifik menunjuk pada keberanian mengatasi ketakutan, mengendalikan risiko, dan keluar dari zona nyaman (comfort zone). Sedangkan keteguhan hati berarti ulet, pantang menyerah; teguh dalam keyakinan (determinasi), dan memiliki keyakinan bahwa "Saya juga bisa" (power of mind). Terakhir, kreativitas menunjuk langsung pada kemampuan berinovasi dan menciptakan hal-hal baru.

Sedangkan Moeljarto Tjokrowinoto secara khusus menguraikan ciri-ciri birokrasi yang berjiwa wirausaha sebagai berikut: (i) bersifat sensitif dan responsif terhadap peluang dan tantangan baru yang timbul di dalam pasar, khususnya sebagai akibat proses globalisasi, liberalisasi, dan regionalisasi perdagangan; (ii) mampu melepaskan diri dari rutinitas kerja yang terkait dengan fungsi instrumental birokrasi dan berani serta mampu melakukan terobosan (breakthrough) melalui pemikiran yang kreatif dan inovatif dalam 
rangka mengatasi sifat-sifat inertia birokrasi; (iii) mempunyai wawasan jauh ke depan (futuristik) dan melihat sesuatu persoalan dalam kaitannya dengan variabel-variabel yang lain (sistemik); (iv) jeli terhadap adanya sumber-sumber potensial baik yang berasal dari dalam negeri maupun luar negeri; (v) mempunyai kemampuan untuk mengombinasikan berbagai sumber menjadi resource mix yang mempunyai efek sinergis dan berproduktivitas tinggi; (vi) mempunyai kemampuan untuk memanfaatkan sumber daya secara optimal, dan menggeser pemanfaat sumber dari kegiatan yang berproduktivitas rendah menuju kepada kegiatan yang berproduktivitas tinggi.

Bisa ditambahkan pada karakteristik-karakteristik di atas, seorang entrepreneurial bureaucrat (birokrat yang berjiwa kewirausahaan) adalah seorang aparatur birokrasi yang tidak pernah merasa puas dengan kondisi dan pencapaian yang sudah ada serta memilki dorongan yang kuat untuk mencapai prestasi (need for achievement). Selain itu, seorang entrepreneurial bureaucrat juga haruslah orang yang berprinsip bahwa kepuasan konsumen (dalam hal ini berarti masyarakat yang dilayani) berada di atas segalanya. Dalam hal terakhir inilah seorang birokrat - terutama sekali bagi para birokrat yang berhubungan langsung dengan masyarakat - sekali waktu perlu dan berani "melanggar prosedur" bila prosedur tersebut justru menghambat efektivitas pelayanannya, tentu dalam batas-batas yang bisa dipertanggungjawabkan dan terukur, yakni dengan koridor dan parameter kepuasan masyarakat tadi. Dengan sendirinya, seorang birokrat yang hanya mencari aman, mengejar kepentingan diri sendiri dan keluarganya, mekanistis-prosedural, dan apriori atau tidak responsif pada perubahan tidak cocok lagi menjadi birokrat dalam era yang telah sangat berubah ini.

Kiranya hanya dengan cara itulah capacity gap sebagaimana telah diuraikan di atas akan tertutupi atau minimal terjembatani.

\section{Beberapa Tantangan}

Entrepreneurial bureaucracy merupakan sebuah cita-cita ideal yang dalam implementasinya tidak akan semudah membalik telapak tangan. Apalagi, birokrasi merupakan mesin pemerintahan yang amat besar dengan budayanya yang telah berurat berakar puluhan tahun. Persis dari sinilah tantangan internal pertama muncul. Mengubah budaya sebuah organisasi yang demikian besar apalagi bila budaya tersebut selama ini 
dirasakan membuat mereka aman dan nyaman membutuhkan waktu yang amat panjang, pun harus dilakukan dengan terencana dan konsisten. Ini jelas merupakan sebuah tantangan yang tidak mudah. Tantangan internal lain adalah sistem keseluruhan birokrasi itu sendiri. Patut direnungkan, sering kali orang tidak bisa bekerja secara produktif bukan karena ia memang tidak produktif, melainkan karena sistemnyalah yang membuat ia tidak produktif. Sebagai contoh, kita bisa menunjuk sistem reward dan punishment yang tidak secara tegas, jelas, dan konsisten diterapkan pada birokrasi kita. Idealnya, sistem harus memungkinkan orang-orang yang memang berprestasi bisa mencapai prestasi setinggi-tingginya sedangkan orang-orang yang tidak kapabel secara alamiah akan tersingkir. Kita tidak menemuinya dalam sistem birokrasi kita. Dalam sebuah diskusi, seorang pegawai negeri di sebuah pemerintahan daerah bahkan sempat melontarkan olok-olok bahwa sistem yang berlaku pada birokrasi kita menyamaratakan saja antara pegawai yang pintar dan pegawai yang bodoh. Hal tersebut menjadi salah satu bukti bahwa sistem yang ada pada birokrasi kita tidak pro-produktivitas, efektivitas, dan efisiensi.

Sedangkan tantangan dari pihak luar (eksternal) salah satunya adalah justru dari para politikus. Terlampau sering terdengar bahwa para politikus sangat suka menggunakan birokrasi sebagai sapi perah. Kasus dana Departemen Kelautan dan Perikanan yang menjebloskan Ruchmin Dahuri ke dalam penjara dan aliran dana Bank Indonesia yang belakangan diributkan merupakan contoh terang benderang mengenai hal itu. Tantangan eksternal lain adalah justru sikap masyarakat yang telah apatis terhadap kinerja birokrasi. Sebenarnya, kontrol masyarakat atas kinerja birokrasi sangat diperlukan sebagai feedback dan bahan evaluasi para aparatur birokrasi. Semakin rakyat bisa dan mau bersikap kritis terhadap birokrasi, semakin birokrasi memperoleh daya dorong untuk mengakselerasi proses reformasi dirinya. Tetapi, ketika kontrol publik menghilang karena berbagai hal salah satunya karena sikap apatis tadi sebetulnya birokrasi sedang kehilangan "sparing partner"-nya yang sangat potensial.

\section{Penutup}


Menutup capacity gap antara kapasitas ideal yang dituntut masyarakat dalam era otonomi daerah dewasa ini dengan kapasitas riil yang saat ini ada pada para aparatur birokrasi kita melalui pembentukan birokrasi yang berjiwa wirausaha (entrepreneur bureucracy) merupakan sebuah agenda amat besar. Berbagai tantangan menghadang di sana seperti telah diuraikan di atas. Namun, sebesar apa pun tantangan yang dihadapi serta seberat apa pun usaha yang harus dijalani, menutup capacity gap tersebut merupakan keharusan bila kita konsisten mengenai semangat inti yang sekaligus harus menjadi muara dari digulirkannya otonomi daerah.

Untuk itu, beberapa langkah strategis di bawah ini barangkali bermanfaat dan mendesak untuk segera dilakukan.

Pertama, bagaimanapun pembentukan birokrasi yang berjiwa wirausaha merupakan sebuah agenda raksasa. Dalam sudut pandang inilah diperlukan sebuah blue print yang antara lain berisi mengenai wajah ideal birokrasi kita di masa depan. Pokok kedua yang mesti terumuskan dalam blue print di atas adalah menyangkut sistem secara keseluruhan. Seperti telah diuraikan di atas, kita pantas curiga bahwa sistem yang ada saat ini sangat mungkin mengandung kelemahan di sana-sini yang memang memungkinkan aparatur birokrasi bekerja tidak efisien, tidak efektif, malas, berbelit, dst. Terhadap kekurangan-kekurangan sistem yang demikian itu, pantas dirumuskan dan diganti dengan sistem yang lebih kondusif bagi pencapaian prestasi, dihargainya kreativitas individu, menjamin kejelasan antara apa yang dilakukan dengan apa yang akan diperoleh, dsb. Di sana harus dirumuskan dengan jelas kriteria-kriteria apa yang harus dimiliki para aparatur birokrasi untuk menjawab tantangan perubahan yang telah bergulir sedemikian cepat. Blue print juga harus memuat strategi, taktik dan langkah-langkah yang jelas dan operasional, terukur dan memuat time line yang tegas. Strategi implementasi dan evaluasi dari masing-masing tahap juga harus dirumuskan dengan jelas. Segala kebijakan perbaikan sistem dan personalia akan selalu memunculkan apa yang disebut the winner (pihak-pihak yang diuntungkan) dan the losser (pihak-pihak yang dirugikan). Justru karena itu, blue print juga harus merumuskan langkah-langkah antisipatif untuk menghindari gejolak yang tidak perlu terutama justru terhadap para losser.

Kedua, terkait tantangan yang dihadapi dalam pembentukan entrepreneurial bureucracy. Untuk tantangan internal, para elit birokrasi harus senantiasa mendorong dan 
memberikan teladan para aparatur birokrat untuk mampu mengubah mindset yang selama ini telah kadung mereka yakini. Birokrat bukan lagi majikan masyarakat melainkan penyedia layanan bagi masyarakat (pelayan publik) dengan segala konsekuensi ikutannya (following consequences). Hanya dengan perubahan mindset lah cita-cita membentuk birokrasi yang kapabel, akuntabel, efektif, efisien, dan luwes; yang dinamis, trengginas, dan responsif mendapatkan titik terangnya. Sedangkan secara eksternal, patut dicamkan dan dilakukan secara konsisten bahwa semua pihak di luar birokrasi (terutama para politikus) tidak boleh lagi memiliki vested interest yang terbukti hanya akan membuat birokrasi kita mandul. Dengan kata lain, semua pihak harus berani memberikan otonomi otentik kepada birokrasi untuk benar-benar hanya melayani kepentingan publik.

Ketiga, sebagai rekan seperjalan dalam perubahan (partner in changes), masyarakat harus diberdayakan untuk mau, berani dan bisa melakukan kontrol objektif atas kinerja birokrasi. Tanpa kondisi yang demikian, birokrasi sebenarnya telah kehilangan satu kakinya untuk menuju perubahan. Dalam hal ini, mengingat sikap masyarakat yang telah telanjur apatis, memang perlu diambil langkah-langkah strategis untuk kembali mengambil hati masyarakat.

Kiranya hanya dengan langkah-langkah riil dan konsekuen seperti itulah otonomi daerah akan sampai pada tujuan semula: kesejahteraan rakyat. Satu yang bisa dijanjikan, ketika birokrasi benar-benar mampu memenuhi kebutuhan masyarakat untuk menggapai kesejahteraannya, pada saat itulah masyrakat akan kembali menaruh trust pada birokrasi; sesuatu yang selama ini telah memudar bahkan hilang!.

\section{Daftar Pustaka}

Bank Dunia, 2008, Pertanian untuk Pembangunan (Laporan Pembangunan Dunia) (terj. oleh Dono Sunardi dan Stefanus Rahoyo), akan terbit.

Hendro, 2005, How to Become A Smart Entrepreneur And to Start A New Business, Yogyakarta: Penerbit Andi.

Suwondo, Kutut, 2005, Otonomi Daerah dan Perkembangan Civil Society di Aras Lokal, Salatiga: Fakultas Ilmu Sosial dan Ilmu Politik Universitas Kristen Satya Wacana.

Turner, Mark, dan Owen Podger, 2003, Decentralisation in Indonesia: Redesigning the State, Australia: Asia Pacifik Press, ANU 
Yuwono, Teguh (ed), 2001, Manajemen Otonomi Daerah: Membangun Daerah Berdasarkan Paradigma Baru, Semarang: CLOGAPSS Diponegoro University.

2001, Public Sector Management: Indonesian Experience, Semarang: CLOGAPSS: Diponegoro University.

\section{Jurnal:}

1. Analisis CSIS, Tahun XXVII/1998, No 1

Tahun XXIX/2000 No 1

Tahun XXXI/2002, No 2 dan No 4

2. Hukum dan Pembangunan, Januari - Maret 2000, Nomor 1 Tahun XXX

3. Kritis, Vol. XII No 3, Maret 2000

4. Yustika, Volume 9 Nomor 1 Juli 2006

\section{Koran dan Majalah}

Harian Kompas, 26 April 2006 dan 6 September 2001

Harian Suara Merdeka, 22 Juli 2002

Manajemen, Mei 2001

Pilars, No 24 Thn VII, 14 - 20 Juni 2004

\section{Makalah:}

Rahoyo, Stefanus, Pendekatan Holistik (Holistic Approach) sebagai Upaya Efektif Pengentasan Kemiskinan, 2007

Susilo, Gideon Tri Budi dan Proyo Hariadi, Analisis Kinerja Keuangan Daerah Sebelum dan Sesudah Otonomi (Studi Empiris di Provinsi Jawa Tengah), 2007

Laporan Indonesian Corruption Watch (ICW), 2004. 